\title{
SSC spectre hovers over neutron project
}

[WASHINGTON] The \$1.4-billion project to build the world's most powerful neutron source at the Oak Ridge National Laboratory in Tennessee has fallen months behind schedule during its first year of construction, and faces major difficulties in obtaining funding for next year.

The Department of Energy is scrambling to sustain support from the Congress for the Spallation Neutron Source (SNS), the largest scientific facility that it has started to build since the abandonment in 1993 of the Superconducting Super Collider (SSC) in Texas.

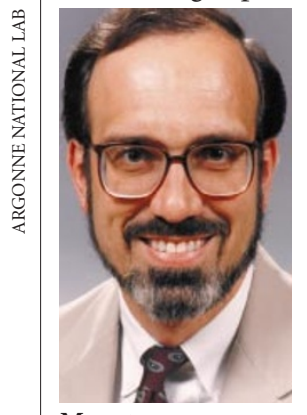

Moncton: a new budget plan by July. It has appointed a highly regarded new project manager, David Moncton of the Argonne National Laboratory, Illinois, who estimates that the project is "three to six months behind schedule" and has promised to prepare a new budget plan by July. Last week Senator Bill Frist (Republican, Tennessee), an important backer of the project, condemned James Sensenbrenner (Republican, Wisconsin), chair of the House Science Committee, for his recent threat to suspend construction funds for the SNS (see Nature 398, 452; 1999). "The Spallation Neutron Source is a vital national project," said Frist. "Sensenbrenner's decision not to support funding for this project is short-sighted."

But Sensenbrenner, a 'budget cutter' noted for his outspoken attacks on projects favoured by the Clinton administration, is not alone in his concern about the project. Senior neutron scientists, a former official at Oak Ridge and an administration official who has supported the project in the past, all say privately that the project has been in trouble since at least last summer.

According to one of the officials, the project faces a credibility problem now because

the energy department did not come clean earlier about the problems Oak Ridge was facing last year. "They said they were hiring people, but there was no project there. I think they are more like a year behind.'

The SNS was developed by the department with Oak Ridge as its preferred site after the Tennessee laboratory's more ambitious plan for a reactor-based facility - the $\$ 3$ billion Advanced Neutron Source — was abandoned in 1995 (see Nature 373, 460; 1995).

The new plan called for the SNS to be built by five laboratories in collaboration: Los Alamos in New Mexico, Brookhaven in New York state and Lawrence Berkeley in California, as well as Argonne and Oak Ridge. This was intended to compensate for Oak Ridge's lack of knowledge of all of the technologies needed, and to boost political support for the project outside Tennessee.

But, according to an independent review commissioned by the energy department in January, the project office at Oak Ridge had been unable to appoint a qualified technical director or to "assert technical leadership" of the whole project. Existing staff had "insufficient experience in the management and leadership of large, complex technical projects," the review said.

The department reacted quickly, appointing Moncton in place of Bill Appleton as project manager in March. "This is the new, fast response Department of Energy!" says Ernie Moniz, the energy under-secretary. "We had a new project manager in two months, and he's already doing an outstanding job."

Moncton built the Advanced Photon Source at Argonne - a project almost as large as SNS - and worked with neutrons early in his research career. He believes the facility can be built on time and within budget. "The most important thing is to attract people to Oak Ridge with expertise in construction and in accelerators and to integrate them with the partner labs, as if everyone was working for the same employer," he says.

Sensenbrenner has praised Moncton's

\section{The many applications of spallation neutrons}

[WASHINGTON] The Spallation Neutron Source being built at Oak Ridge (see above) would have a power rating of 2 megawatts - more than 10 times greater than that of ISIS in the United Kingdom, currently the world's best neutron spallation source.

A spallation source generates pulses of neutrons by firing a proton beam at a heavy-metal target - made of liquid mercury at the planned US facility - which then gives off neutrons at a wide range of energies.

Materials scientists, condensed-matter physicists and structural biologists use neutrons to study crystalline and molecular structures. Although more difficult to generate than $\mathrm{X}$-rays, they are preferred for some applications because they pick up images of lighter atoms which $\mathrm{X}$-rays miss.

The average flux of neutrons produced by a spallation source is weaker than that delivered by other neutron sources based on nuclear reactors. But skilled experimentalists can make use of the sharp pulses of neutrons at the variety of energies that a spallation source will deliver.

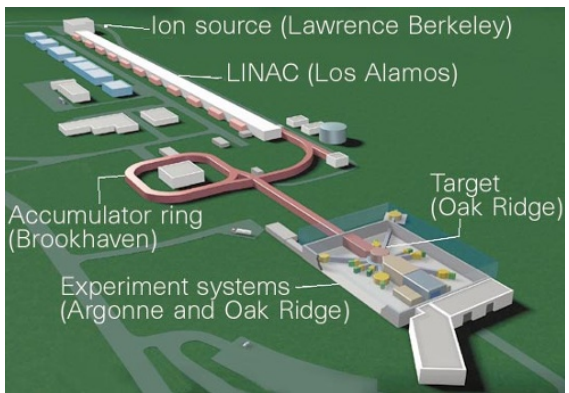

Coming together: layout of the SNS, combining expertise from five collaborating laboratories.

appointment. But he remains worried about a \$35-million 'use tax' that the state of Tennessee plans to levy on the project, as well as management and staffing problems. "I'm concerned that this is starting to establish a pattern of slippage," he says. "What this programme needs is some tough love. I'm darned if there's going to be another SSC fiasco on my watch."

Opponents of Sensenbrenner accuse him of attacking the project because it is in the home state of Al Gore, the likely Democrat nominee in the next presidential elections. Sensenbrenner, they point out, needs to curry favour with the House Republican leadership, which he hopes will promote him to chair the Judiciary Committee in the next Congress, and the leadership is running a 'get Gore' campaign to attack the vice-president on every front.

But the project's problems are real enough. It has been difficult to hire senior staff because the top management at Oak Ridge, including the director, Alvin Trivelpiece, will probably leave next March when Lockheed Martin, the contractor which manages the laboratory for the energy department, is expected to be replaced.

Appleton, the former SNS project manager who is now deputy director of Oak Ridge, denies that the SNS was as much as three months late under his charge. "The project was judged in January to be OK," says Appleton, a respected neutron scientist and administrator who says that "too much has been made" of problems on the project.

Trivelpiece says it was hard to keep the project on schedule because it is illegal to prepare for the use of funds until they are actually appropriated. "The money we had was parsed out in the most intelligent way possible," says Trivelpiece, who stresses that the energy department was kept fully informed of the project's status.

Asked who was responsible for the project running late, Martha Krebs, assistant secretary of energy, says: "What we've done is to make sure we don't get any further behind. I don't think it is useful to point fingers."

ColinMacilwain 